\title{
Extradition and Constitution (Article 35.3 of the Somaliland Constitution)
}

Anton Girginov*

A former State Prosecutor and University Professor, PhD, DSc; International Prosecution Adviser in Mogadishu with European Union Capacity Building Mission

DOI: $10.36348 /$ sijlcj.2020.v03i05.003

| Received: 08.05.2020 | Accepted: 15.05.2020 | Published: 17.05.2020

*Corresponding author: Anton Girginov

Abstract

Constitutions of new countries are expected to facilitate extradition relations as well as other modalities of international judicial cooperation with other countries. This is specifically important for countries, such as Somaliland, which seek recognition of their independence. However, in some cases, their Constitutional provisions do not succeed in materializing the right balance between national interests and the interest in fighting crime at the international level. As a result, the Constitution of such countries may even hurdle efficient extradition relation and eventually, isolate the country from the joint struggle against crime. This seems to be the case of Article 35 (3) of the Somaliland Constitution, in particular. This research paper is designed to explain the weaknesses of the aforementioned Paragraph 3 and provide some ideas for its improvement.

Keywords: Constitution, extradition, international treaty, agreement, law, reciprocity, Somaliland.

Copyright @ 2020: This is an open-access article distributed under the terms of the Creative Commons Attribution license which permits unrestricted use, distribution, and reproduction in any medium for non-commercial use (NonCommercial, or CC-BY-NC) provided the original author and source are credited.

\section{INTRODUCTION}

Extradition consists of handing over to another country a fugitive who was accused or convicted by its competent authorities of a criminal offence. The fugitive is surrendered to that country for the purposes of his/her prosecution or punishing in its territory and in accordance with its laws. Extradition is granted and executed on the basis of a prior request by this country to the country of the fugitive location. As other modalities of international judicial cooperation in criminal matters extradition is governed, mostly, by the rules of the requesting country. Usually, its ordinary law contemplates the rules which govern extradition. However, one or more rules governing extradition may be found in the Constitution of this country as well. Somaliland is also such a country. Article 35 [Extradition of the Accused and Convicted Persons ...], Paragraphs 2 and 3 of its Constitution represent the basic rules designed to regulate extradition to foreign countries.

This paper is focused specifically on Paragraph 3 of this Article. The Paragraph in the issue reads as follows: "The Republic of Somaliland may extradite to their countries convicted or accused foreigners if there is a treaty between the Republic of Somaliland and the country requesting their extradition". Therefore, extradition might be treaty-based only. This concept of extradition is out-dated. This is why the competent authorities of Somaliland might be strongly advised to overcome it given the arguments stated further in the text.

\section{The problem with the treaty-based extradition}

Not only Article 35 (3) of the Somaliland Constitution but also Article 11.1 (b) of the Penal Code in conjunction with Article 130 (5) of the Constitution stipulates that a fugitive to the territory of Somaliland "may be extradited ... on the basis of an international treaty or convention which the Federal Republic of Somalia \{Somaliland, respectively\} is a party to". Therefore, the Somaliland law allows treaty-based extradition only. Ordinary legislation of Somaliland alone cannot change anything. It must stay within this Constitutional treaty concept of Article 35 (3). Otherwise, any law disregarding this concept would eventually not conform to the Somaliland Constitution and shall be null and void - see Article 128.2 of the Constitution.

Thus, under the current Constitution of Somaliland, it is not possible to extradite a fugitive from Somaliland under any extra-treaty condition, including reciprocity. This, in turn, considerably narrows the possibilities of obtaining extradition from another country if there is no extradition agreement with it. 
Somaliland does not contemplate reciprocity relations, although it belongs to the Civil Law (Latin) legal family $\left[{ }^{1}\right]$ and even the Muslim countries from this family extradite under reciprocity - Article 1 of the Iranian Law on Extradition $\left[^{2}\right]$, Article 52 of the Iraqi CPC, Article 365 (1) (3) (ii) of the CPC of Kazakhstan, Article 2 of the UAE Law on International Judicial Cooperation in Criminal Matters, etc. It is to be clarified that reciprocity relations are the typical extra-treaty condition for rendering international judicial cooperation $\left[{ }^{3}\right]$.

Hence, Somaliland cannot rely on any reciprocity with countries that it has no agreement with. As the authorities of this country do not consider their extradition requests, Somaliland cannot expect, in turn, any cooperation from them either. Even if Somaliland promises to the country, which it approaches to consider its future extradition requests, no relation of reciprocity with that foreign country would be invoked. The problem is that the Somaliland promise would not be accepted as its laws prevent it from being kept. Therefore, it would be an invalid promise producing no legal consequences.

2. In theory, Somaliland may expect non-treaty based extradition from common law (Anglo-Saxon) countries unless they are like Kenya which also sticks to the treaty-based extradition only. Usually, these countries do not work with reciprocity. Their extratreaty condition, if any, is based on the so-called "designated countries list". Such lists are produced unilaterally by the central state authorities of those

1. Although Somaliland was a British protectorate, the merger with South Somalia altered the legal tradition of the nation. Hence, the common law was overruled by the civil law tradition. See also on this legal legacy issue:

https://www.nyulawglobal.org/globalex/Somaliland.ht $\mathrm{ml}$, accessed on 28 Jan 2020.

2. This article reads: "If there is an extradition treaty concluded between Iran and foreign states, extradition should be performed according to the provisions of that treaty, and if there is no extradition treaty or an extradition treaty is concluded but it does not include all required points, extradition should be performed according to the conditions of this law subject to reciprocal treatment."

${ }^{3}$. Such relations are invoked if the interested country has already considered (not necessarily granted) an extradition request from the other country; the interested country has just to mention this in the request to the other country. This is how reciprocity by action is invoked. Subsidiarily, if the interested country has not considered in the past any extradition request from the country which it approaches now, this interested country should promise/declare to it its readiness to consider, in turn, its future requests. This is the way to invoke reciprocity by words. countries. If the requesting country, including Somaliland, is on this list, the judicial authorities there would consider its request. Otherwise, if it is not, then most probably no consideration will be given to the request.

Actually, Somaliland may expect effective non-treaty based cooperation from the few countries which do not restrict themselves to the abovementioned extra-treaty conditions for judicial cooperation. These countries are more flexible and render cooperation also under other extra-treaty conditions. Such, for example, are the following civil law (Latin/ Continental-European) countries: Hungary (Section 6, para. 2 of the Hungarian Law on International Legal Assistance in Criminal Matters), Portugal (Article 6.1, "f" of the Portuguese Law on International Judicial Cooperation in Criminal Matters) and Romania (Article 5, para. 3 of the Romanian Law on International Legal Assistance in Criminal Matters). The absence of reciprocity does not impede the judicial authorities of these countries if the cooperation: (a) is seen to be advisable in view of the nature of the facts, or in view of the need to combat certain serious forms of criminality; (b) may benefit the person concerned; or/and (c) may serve to shed light on facts related to own nationals. Finally, Article 2 (2) of the Indonesian Law No. 1/1979 on Extradition is also in the same sense. It reads as follows: "In the event that no treaty as mentioned in para. 1 above has been drawn, extradition may be initiated based on good relations and if the interests of the Republic of Indonesia requires it".

However, all such countries are exceptions which are not likely to easily grant extradition requests to Somaliland as well as to similar new and unknown countries. This is why the Somaliland authorities cannot be advised to rely on such exceptions but try to modernize its extradition law by also opening it to nontreaty based cooperation.

\section{Critical notes on article 35 (3) of the somaliland constitution}

1. Most probably, the existing restriction under Article 35 (3) of the Somaliland Constitution to treatybased extradition only comes from the reception of Article 26 (1) of the Italian Constitution. This provision of the Italian Constitution reads as follows: "Extradition of a citizen may be granted only if it is expressly envisaged by international conventions". However, Italy is not an appropriate example for Somaliland in this regard. This European country has a lot of extradition agreements with other countries and the position and capacity to negotiate, sign and ratify many more. Compared to Italy, Somaliland has definitely fewer extradition agreements with other countries and is not likely to have many more soon. Actually, Somaliland may be treated as a Party to only one such agreement, namely: the 1983 Riyadh Arab Agreement for Judicial Cooperation [the so-called "Riyadh Convention"]. Its Articles 38-57 directly govern 
extradition. This basic legal instrument of the Arab world was ratified by the Democratic Republic of Somalia on the 21 st of October 1985 and it is valid to Somaliland in accordance with Article 130.5 of the Somaliland Constitution. However, beyond the scope of this international legal instrument, Somaliland needs to rely on non-treaty based extradition for a long period of time.

Most likely, only the Provisional Constitution of Somalia [see Article 36] contains a voluntary selfrestriction to treaty-based extradition. Undoubtedly, this restriction is counterproductive. There is no justification for (let alone benefit from) any such restriction as it solely leads the country to isolation. Therefore, Somaliland needs to open the way to non-treaty based extradition as well by deleting the text of Article 35 (3) of its Constitution. As a result, the extradition agreements (bilateral and multilateral) will not necessarily be the only ground for granting and executing incoming requests for extradition.

Moreover, it is not necessary, at all, that the Constitution contemplates the grounds for extradition, whatever they are (treaty or non-treaty). On the contrary, in most countries, these grounds are found only in ordinary laws. This is valid even for countries which recognize the treaty-based extradition only. For example, Kenya, which also sticks only to the treatybased extradition, does not lay down this legal restriction in the Constitution. This exclusive treaty ground for extradition exists only in Article 3, Para 1 of the Extradition (Contiguous and Foreign Countries) Act of Kenya.

2. For the purposes of comparison with Kenyan extradition law it is worth recalling that in February 2020, the Somali Federal Government made a mistake by issuing a red notice for the provisional extradition detention of fugitive [the Jubbaland Security Minister Abdirashid Janan], who was located in Kenya which Somalia has no extradition treaty and which carries out only treaty-based extradition. Extradition arrests and detentions are procedural restrictions, designed solely to secure the presence of an arrestee/detainee in the potential extradition proceedings against him, which would commence on the basis of a future formal/official extradition request from the country that wants his surrender. However, if such proceedings in the requested country are not possible at all (in our case, because the requested country, Kenya, carries out only treaty-based extradition and the requesting one, Somalia, has no such treaty with it), no procedural restriction on the wanted person (his deprivation of liberty, in particular) can be justified there. As a result, his arrest and detention shall be denied, and his extradition would be unthinkable. Because all the information is already public (even if the red notice would not be circulated via the Interpol channel), this fugitive would inevitably realise that
Somalia wants to obtain his extradition and would remain in Kenya to stay beyond the reach of the Somali efforts to bring him back.

At the same time, a symptomatic statement was issued by the authorities of Somalia. It reads: "The Federal Republic of Somalia places great importance on maintaining good relations with its neighbouring countries and the harbouring of a dangerous fugitive could seriously jeopardise the good relations that has (sic) so far existed between Kenya and Somalia." $\left[{ }^{4}\right]$. It is worth noting, however, that Somalia is even more hostile to extradition than Kenya. Indeed, both countries stick to the treaty-based extradition only and per argumentum a contrario prohibit other, non-treaty based extradition. Yet, the Somali legal restriction to the treaty-based extradition is stronger as it is laid down in its Provisional Constitution - Article 36 (1) \{ which is no different from the current Article 35 (3) of the Constitution of Somaliland, regretfully\}. As a result, no ordinary law can change anything; it cannot allow, in particular, any non-treaty based extradition, such as the one based on reciprocity or the one based on the interests of justice. Any law, introducing such grounds for extradition, would run contrary to the prohibition under Article 4 (1) (i) of the Somali Provisional Constitution.

The legislative situation with Kenya is definitely better. Like most other countries in the world, Kenya regulates the conditions for extradition in ordinary law, namely: Article 3, Paragraph 1 of the Kenyan Extradition (Contiguous and Foreign Countries) Act [a different one exists for the Commonwealth Countries]. It is changeable by another ordinary law. This is why Kenya is more flexible and adaptive to the new realities and requirements in the area of extradition as well as the other modalities of international judicial cooperation.

This is why it would be a step forward if Somaliland follows the same approach of regulating the conditions for extradition in ordinary law. Hence, it would be a step in the right direction if Somaliland abandons Para 3 of Article 35 of its Constitution. Thereafter, the legislative authorities of this country would be free to decide in their respective ordinary law what extra-treaty ground for extradition to have, if any: the reciprocity as in many civil law countries or the interest of justice consideration as in Hungary, Indonesia, Romania and Portugal.

Thus, if the Somaliland authorities do not agree to abolish the restriction to the treaty-based extradition from their legal system altogether, they

4 See

https://www.hiiraan.com/news4/2020/Feb/167029/soma lia_engages_interpol_to_arrest_janan_urges_ kenya_to_extradite_him.aspx, accessed on 15 Feb 2020. 
should, at least, remove it from their Constitution by deleting the text of Article 35 (3). The restriction to the treaty-based extradition shall not be any Constitutional issue. Otherwise, its existence in the Somaliland Constitution would, most of all, prevent Somaliland from modernizing its extradition relations which is achievable, usually, by ordinary laws.

3. Actually, if some extradition issue is addressed by a Constitution, at all, it is, most often, the extradability of own nationals. This makes Paragraph 2 of the Somaliland Constitution sufficient for the Constitutional regulation of extradition issues. Like most Constitutions of civil law countries (Somaliland is such thanks to the Italian legal legacy), this Constitution also imposes a general prohibition on the extradition of their nationals $\left[{ }^{5}\right]$. It is noteworthy at the end that this prohibition is not necessarily in the Constitution. In many other civil law countries, only non-constitutional (ordinary) laws contain it $\left[{ }^{6}\right]$.

Either way, in civil law countries the nonextradability of own nationals shall not entail exemption from criminal liability even for criminal offences committed abroad. Such exemption from criminal liability is avoided by the extraterritorial applicability of their countries' penal laws on the ground that the crimes are committed by own nationals. Because Somaliland and other civil law countries apply extraterritorially their national criminal laws and therefore, can hold their nationals responsible for crimes committed by them in other countries as well, they do not need to extradite them to these countries for prosecution, trial and punishment. Moreover, if such countries refuse extradition on the ground that the wanted person is their national, they are often legally obliged to prosecute him/her for the crime in respect of which $s /$ he was requested if the requested country so demands after the refusal, e.g. Article 6 (2) of the European Convention on Extradition.

\footnotetext{
${ }^{5}$.At the same time, some of these Constitutions, e.g. of Bulgaria, Egypt, Poland, Romania, UAE, contemplate, in addition, exceptions to this general rule. The exceptions in the issue refer to international agreements, obliging the extradition of own nationals also. Such Constitutions contain provisions, which allow the international agreements in the issue to override the general prohibition on the extradition of own nationals. See, for example, Article 25.4 of the Bulgarian Constitution, Article 55.2 of the Polish Constitution and Article 19.2 of the Romanian Constitution.

6 . In many countries, non-constitutional laws contain this prohibition, e.g. Article 358.4 of the Iraqi Criminal Procedure Code, Article 493bis (A), letter "d" of the Libyan Criminal Procedure Code, Article 9.1 of the UAE Law on International Judicial Co-operation in Criminal Matters and also Article 18.1 of the Turkish Penal Code postulating that only foreigners are extraditable.
}

It is noteworthy, however, that under applicable law no such second demand of the requesting country is required for obliging the Somaliland authorities to prosecute the wanted Somalilander. According to Article 8 (2), letter "d" of the Penal Code in conjunction with Article 130 (5) of the Somaliland Constitution, the Somali Penal Code is applicable to the crime of this person and, therefore, s/he should be prosecuted for his/her crime, irrespective of the will of the requesting country. The problem is that Somaliland may take over cases for which its authorities may not be able to find sufficient evidence. This is why some restrictions for such prosecutions may be justified. For example, in this case when the refusal for extradition is based on the Somaliland nationality of the wanted person, the application of the Penal Code shall be triggered also as per the next letter ["e"] of Article 8 (2) of the Penal Code, cumulatively, namely: if, in addition, "the prosecution is authorized by the Minister of Grace and Justice". Certainly, the same shall be the result, if an applicable international extradition agreement obliges Somaliland authorities to prosecute the person at the requesting country's demand when his/her extradition has been rejected on the grounds that $\mathrm{s} / \mathrm{he}$ is a Somalilander.

\section{Extradition and asylum under article 35 (1) of the somaliland constitution}

According to Paragraph 1 of Article 35 of the Constitution, "Any foreigner who enters the country lawfully or is lawfully resident in the country and who requests political asylum may be accorded asylum if he fulfils the conditions set out in the law governing asylum". This provision precedes Paragraphs 2 and 3 of the same Article addressing extradition issues. This is why it would be important to find whether the granted asylum alone constitutes an impediment to extradition from Somaliland.

Asylum issues are regulated by the 1951 Convention Relating to the Status of Refugees. Somalia acceded to it on 10 October 1978. As a result, pursuant to Article 10 (1) of the Somaliland Constitution, this Convention is binding Somaliland.

As per Article $1 \mathrm{~F}$ of this Convention, "The provisions of this Convention shall not apply to any person with respect to whom there are serious reasons for considering that:

(a) he has committed a crime against peace, a war crime, or a crime against humanity, as defined in the international instruments drawn up to make provision in respect of such crimes;

(b) he has committed a serious non-political crime outside the country of refuge prior to his admission to that country as a refugee; 
(c) he has been guilty of acts contrary to the purposes and principles of the United Nations".

Such crimes, excluding the application of the Convention, are ascertainable in extradition proceedings. Asylum proceedings cannot ignore their result but shall take into account their results. It follows that when under extradition law the requested extradition of a given person shall be granted, asylum law is in no position to prevail and eventually, prevent the surrender of the person to the requesting country.

On the contrary, findings in the extradition process may [not only in respect of crimes under Article $1 \mathrm{~F}$ of the Convention but in respect of all other extraditable crimes as well] have a bearing not only on the eligibility for international refugee protection of an asylum-seeker. They are also likely to affect the status of a refugee who has already been recognized. Information which comes to light during the extradition process may also set in motion proceedings leading to the revocation of the status of a recognized refugee on the basis of Article $1 F$ (a) or (c) of the 1951 Convention. Such information would cast doubt on the correctness of the initial refugee recognition, which in turn may result in the cancellation of refugee status.

Obviously, extradition and asylum do overlap where the person, whose extradition is sought, is a refugee or asylum-seeker. However, international refugee law does not as such stand in the way of criminal prosecution or the enforcement of a sentence, nor does it generally exempt refugees and asylumseekers from extradition. As the institution of asylum was never intended to shield fugitives from legitimate criminal justice, this institution shall not be seen as a restriction to application of extradition law.

Hence, extradition excludes asylum but asylum does never exclude extradition. In civil law countries, including Somaliland, extradition may be excluded only by granting nationality to the person - in addition to his/her refugee status or without giving him/her such a status.

Actually, the granted asylum may prevent extradition from being granted only in the few cases when the applicable international law does not prohibit the surrender of the the wanted person to countries where s/he might be grossly discriminated. In such cases, extradition shall be rejected by virtue of Article 33 (1) of the Convention Relating to the Status of Refugees: ,where his life or freedom would be threatened on account of his race, religion, nationality, membership of a particular social group or political opinion". However, most of the extradition agreements as well as national extradition laws contain such ground for refusal. Given the tentative recommendation that Somaliland should open the way to non-treaty based extradition, it might be further recommended that its national law should contemplate this ground for refusal as well. Thus, Somaliland would be on the safe side. It would be able to refuse extradition to countries where the wanted person might be grossly discriminated, even if no applicable international law prohibits his/her extradition.

\section{CONCLUSIONS}

The non-recognition of the independence of a given country does not exclude international judicial cooperation with this country. The non-recognition of its independence may affect, mostly, the communication channels with (to and from) the country. Thus, the countries, which have not recognized Kosovo as an independent country, communicate with its authorities through the UN mission there: UNMIK.

At the same time, even those countries, the independence of which is recognized by all other countries in the world, cannot rely only on international judicial cooperation based on international agreements (bilateral and multilateral). The need for such cooperation, including extradition, grows every day and even the biggest and most powerful countries cannot have agreements with all other countries in the world. Per argumentum a fortiori, when it comes to smaller countries, the number of their agreements with other countries is inevitably and significantly smaller as well. Hence, if the Constitution of a smaller country excludes non-treaty based international judicial cooperation, such a country unjustifiably isolates itself from the support, which it may obtain from other countries in fighting crime. Obviously, most isolated would be the small countries, the independence of which has not yet been recognized. This isolation, in turn, makes their way to recognized independence longer. In short, if somebody has put chains on his/her hands by mistake or out of lack of information, s/he should be advised to remove them as quickly as possible.

\section{REFERENCES}

1. Bassiouni, M. Cherif. (2014). International Extradition: United States Law and Practice, $6^{\text {th }}$ edition, Oxford and Bassiouni, M. Ch. and Wise, E. M., 1995, Aut Dedere Aut Judicare: The Duty to Extradite or Prosecute in International Law, Dordrecht, Martinus Nijhoff Publishers.

2. Bernacchi, M. B. (1992). Standing for the Doctrine of Specialty in Extradition Treaties: A More Liberal Exposition of Private Rights, 25(4), LOY. L.A. Int'l \& Comp. Law Review, p. 1377. Retrieved on 12 May 2019 from https://digitalcommons.lmu. edu/llr/vol25/ iss4/15/.

3. Girginov, A. (2019). Extradition and Human Rights in Somalia, in "International Journal of Recent Innovations in Academic Research", 1(3)18.

4. Handbook on the International Transfer of Sentenced Persons, United Nations Office on Drugs and Crime, Vienna, New York, 2012. 
5. Hedges, R. J. (2014). International Extradition: A Guide for Judges, Federal Judicial Center, USA, 22.

6. IRNA, 13 February (2019). Iran extradites 10 Somalia Convicts. Retrieved on 23 July 2019 from https://en.irna.ir/news/83208644/Iran-extradites10-Somalia-convicts.

7. Kapferer, S., (2003). The Interface between Extradition and Asylum, in "Legal and Protection
Policy Research Series", UNHCR, Geneva, Switzerland.

8. Shearer, I. A. (1970). Extradition in International Law, Manchester, University of Manchester Press.

9. Бойцов, Александр, И. (2004). Выдача преступников, "Юридический центр", СанктПетербург. 